Vol 1. No. 4, Oktober 2021 P-ISSN : 2774-8014, e-ISSN : 2774-7034

\title{
UPAYA MENINGKATKAN PRESTASI BELAJAR MATEMATIKA LEWAT METODE PEMBELAJARAN MODEL KONTEKSTUAL BERBASIS MASALAH
}

\author{
SUGIATI \\ SD Negeri 015 Petala Bumi \\ e-mail: sugiatispd70@gmail.com
}

\begin{abstract}
ABSTRAK
Bagaimanakah caranya agar siswa tidak melupakan materi pelajaran yang telah diterimanya agar siswa nantinya siap menghadapi ujian kenaikan kelas yang siap atau tidak siap harus mereka hadapi. Bagaimanakah membuat suatu materi ajar agar agar tidak terlupakan oleh anak didik. Dalam hal ini guru harus mencari metode untuk mengingatkan segala memori di benak siswa yang telah mereka terima. Guru harus bisa membangkitkan kembali memori itu. Penelitian ini menggunakan penelitian tindakan (action research) sebanyak tiga putaran. Sasaran penelitian ini adalah siswa kelas VI SD Negeri 015 Petala Bumi, Data yang diperoleh berupa hasil tes formatif, lembar observasi kegiatan belajar mengajar. Dari hasil analis didapatkan bahwa prestasi belajar siswa mengalami peningkatan dari siklus I sampai siklus III yaitu, siklus I (66,67\%), siklus II (76,19\%), siklus III (90,48\%). Kesimpulan dari penelitian ini adalah metode kontekstual berbasis masalah materi pelajaran dapat berpengaruh positif terhadap motivasi belajar Siswa kelas VI SD Negeri 015 Petala Bumi serta model pembelajaran ini dapat digunakan sebagai salah satu alternatif pembelajaran Matematika.
\end{abstract}

Kata Kunci : Matematika, kontekstual

\section{PENDAHULUAN}

Pada hakekatnya kegiatan belajar mengajar adalah suatu proses interaksi atau hubungan timbal balik antara guru dan siswa dalam satuan pembelajaran. Guru sebagai salah satu komponen dalam proses belajar menganjar merupakan pemegang peran yang sangat penting. Guru bukan hanya sekedar penyampai materi saja, tetapi lebih dari itu guru dapat dikatakan sebagai sentral pembelajaran.

Berhasilnya tujuan pembelajaran ditentukan oleh banyak faktor diantaranya adalah faktor guru dalam melaksanakan proses belajar mengajar, karena guru secara langsung dapat mempengaruhi, membina dan meningkatkan kecerdasan serta keterampilan siswa. Untuk mengatasi permasalahan di atas dan guna mencapai tujuan pendidikan secara maksimal, peran guru sangat penting dan diharapkan guru memiliki cara/model mengajar yang baik dan mampu memilih model pembelajaran yang tepat dan sesuai dengan konsep-konsep mata pelajaran yang akan disampaikan.

Tujuan pendidikan nasional seperti yang terdapat dalam Undang-undang pasal 3 Nomor 20 tahuan 2003 yaitu Pendidikan nasional berfungsi mengembangkan kemampuan dan membentuk watak serta peradaban bangsa yang bermartabat dalam rangka mencerdaskan kehidupan bangsa, bertujuan untuk berkembangnya potensi peserta didik agar menjadi manusia yang beriman dan bertakwa kepada Tuhan Yang Maha Esa, berakhlak mulia, sehat, berilmu, cakap, kreatif, mandiri, dan menjadi warga negara yang demokratis serta bertanggung jawab .Tujuan pendidikan nasional ini sangat luas dan bersifat umum sehingga perlu dijabarkan dalam Tujuan Institusional yang disesuaikan dengan jenis dan tingkatan sekolah yang kemudian dijabarkan lagi menjadi tujuan kurikuler yang merupakan tujuan kurikulum sekolah yang diperinci menurut bidang studi/mata pelajaran atau kelompok mata pelajaran (Permendikbud nomor 62 tahun 2014). Bahwa pengembangan potensi peserta didik sebagaimana dimaksud dalam tujuan pendidikan nasional dapat diwujudkan melalui kegiatan ekstrakurikuler yang merupakan salah satu kegiatan dalam program kurikuler.

Dalam mencapai Tujuan Pembelajaran Khusus pada mata pelajaran Matematika di SDN 015 Petala Bumi khususnya di Kelas VI masih banyak mengalami kesulitan. Hal ini terlihat dari masih rendahnya nilai mata pelajaran Matematika dibandingkan dengan nilai beberapa 
mata pelajaran lainnya, mata pelajaran Matematika peringkat nilainya menempati urutan paling bawah dari enam mata pelajaran . Banyak siswa memandang matematika sebagai bidang studi yang paling sulit. Padahal Dimyati dan Mujiono (2013: 238) mengemukakan bahwa dalam proses belajar siswalah yang menentukan terjadi atau tidaknya. Untuk bertindak belajar siswa menghadapi masalah-masalah secara intern. Jika Bertitik tolak dari hal tersebut di atas perlu pemikiran-pemikiran dan tindakan-tindakan yang harus dilalukan agar siswa dalam mempelajari konsep-konsep Matematika tidak mengalami kesulitan, sehingga tujuan pembelajaran khusus yang dibuat oleh guru mata pelajaran Matematika dapat tercapai dengan baik dan hasilnya dapat memuaskan semua pihak. Oleh sebab itu penggunaan metode pembelajaran ini dirasa sangat penting untuk membantu siswa dalam memahami konsepkonsep Matematika.

Penggunaan metode Kontekstual Berbasis Masalah diharapkan dapat meningkatkan aktivitas siswa dalam proses belajar mengajar sehingga dalam proses belajar mengajar itu aktivitasnya tidak hanya didominasi oleh guru, dengan demikian siswa akan terlibat secara fisik, emosional dan intelektual yang pada gilirannya diharapkan konsep perubahan benda yang diajarkan oleh guru dapat dipahami oleh siswa. Berdasarkan uraian dari latar belakang tersebut di atas maka dalam penelitian ini memilih judul "Penerapan Metode Kontekstual Berbasis Masalah" Untuk Meningkatkan Hasil Belajar Matematika Pada Siswa Kelas VI di SD Negeri 015 Petala Bumi.

\section{METODE PENELITIAN}

Model Kontekstual Berbasis Masalah adalah salah suatu pendekatan pengajaran yang menggunakan masalah dunia nyata sebagai suatu konteks bagi siswa untuk belajar tentang berfikir kritis dan keterampilaan pemecahan masalah,serta untuk memperoleh pengetahuan dan konsep yang esensi dari materi pelajaran. Guru harus mampu menyusun rumusan tujuan instruksional, agar guru dapat memberi motivasi yang kuat pada siswa untuk belajar.

Agar Metode Pembelajaran Model Kontekstual Berbasis Masalah di SD Negeri 015 Petala Bumi ini dapat terlaksanana dengan baik, maka penulis melakukan hal-hal sebagai berikut:

1. Mempertimbangkan baik-baik apakah pilihan teknik yang penulis terapkan mampu menjamin tercapainya tujuan yang telah dirumuskan.

2. Mengamati apakah jumlah siswa memberi kesempatan untuk suatu model pemebelajaran yang berhasil. Bila tidak penulis akan mengambil kebijaksaaan lain.

3. Penulis menentukan garis besar langkah-langkah yang akan dilakukan.

4. Penulis perlu mengadakan evaluasi apakah model pembelajaran yang dilakukan itu berhasil, dan bila perlu Model Kontekstual Berbasis Masalah ini bisa diulang.

Penggunaan teknik Model Kontekstual Berbasis Masalah sangat menuntut pemikiran yang kritis belajar di kelas. Keuntungan yang diperoleh ialah, dengan Model Kontekstual Berbasis Masalah perhatian siswa lebih dapat terpusatkan pada pelajaran yang sedang diberikan, kesalahan-kesalahan yang terjadi bila pelajaran itu direncanakan dapat diatasi melalui pengamatan dan contoh kongkrit. Sehingga kesan yang diterima siswa lebih mendalam dan tinggal lebih lama pada jiwanya. Akibatnya selanjutnya memberikan motivasi yang kuat untuk siswa agar lebih giat belajar.Maka kadang-kadang dalam pemakaian teknik mengajar itu penulis perlu menyertai dengan teknik yang lain, atau mengombinasikan dengan lain, sehingga mampu mengatasi teknik inti yang sedang dimanfaatkan . Penulis berharap Model Kontekstual Berbasis Masalah ini siswa di SD Negeri 015 Petala Bumi dapat partisipasi aktif, dan memperoleh pengalaman langsung, serta dapat mengembangkan kecakapannya.

\section{HASIL DAN PEMBAHASAN}

Belajar dapat membawa suatu perubahan pada individu yang belajar. Perubahan ini merupakan pengalaman tingkah laku dari yang kurang baik menjadi lebih baik. Pengalaman 
dalam belajar merupakan pengalaman yang dituju pada hasil yang akan dicapai siswa dalam proses belajar di sekolah. Menurut Poerwodarminto (1991: 768), Hasil Belajar belajar adalah hasil yang dicapai (dilakukan, dekerjakan), dalam hal ini Hasil Belajar belajar merupakan hasil pekerjaan, hasil penciptaan oleh seseorang yang diperoleh dengan ketelitian kerja serta perjuangan yang membutuhkan pikiran.

Berdasarkan uraian diatas dapat dikatakan bahwa Hasil Belajar belajar yang dicapai oleh siswa dengan melibatkan seluruh potensi yang dimilikinya setelah siswa itu melakukan kegiatan belajar. Pencapaian hasil belajar tersebut dapat diketahui dengan megadakan penilaian tes hasil belajar. Penilaian diadakan untuk mengetahui sejauh mana siswa telah berhasil mengikuti pelajaran yang diberikan oleh guru. Di samping itu guru dapat mengetahui sejauh mana keberhasilan guru dalam proses belajar mengajar di sekolah.

Sejalan dengan Hasil Belajar belajar, maka dapat diartikan bahwa Hasil Belajar belajar Matematika adalah nilai yang dipreoleh siswa setelah melibatkan secara langsung/aktif seluruh potensi yang dimilikinya baik aspek kognitif (pengetahuan), afektif (sikap) dan psikomotor (keterampilan) dalam proses belajar mengajar Matematika.

\section{Hasil}

Ada dua kategori ketuntasan belajar yaitu secara perorangan dan secara klasikal. Berdasarkan petunjuk pelaksanaan belajar mengajar kurikulum 1994 (Depdikbud, 1994), yaitu seorang siswa telah tuntas belajar bila telah mencapai skor $65 \%$ atau nilai 65 , dan kelas disebut tuntas belajar bila di kelas tersebut terdapat $85 \%$ yang telah mencapai daya serap lebih dari atau sama dengan $65 \%$.

Untuk menghitung persentase ketuntasan belajar digunakan rumus sebagai berikut: Peneliti melakukan penjumlahan nilai yang diperoleh siswa, yang selanjutnya dibagi dengan jumlah siswa yang ada di kelas tersebut sehingga diperoleh rata-rata tes formatif. Untuk menghitung persentase ketuntasan belajar digunakan rumus sebagai barikut:

$$
\bar{X}=\frac{\sum X}{\sum N}
$$

Dengan

$$
\begin{aligned}
: \bar{X} & =\text { Nilai rata-rata } \\
\Sigma \mathrm{X} & =\text { Jumlah semua nilai siswa } \\
\Sigma \mathrm{N} & =\text { Jumlah siswa } \\
P & =\frac{\sum \text { Siswa.yang.tuntas.belajar }}{\sum \text { Siswa }} \times 100 \%
\end{aligned}
$$

Data penelitian berupa pengamatan pengelolaan belajar dan penilaian guru pada akhir pembelajaran berupa data tes formatif siswa pada setiap siklus.

\section{Siklus I}

\section{a. Tahap Perencanaan}

Pada tahap ini peneliti mempersiapkan perangkat pembelajaran yang terdiri dari rencana pelajaran 1, LKS 1, soal tes formatif 1 dan alat-alat pengajaran yang mendukung.

b. Tahap Kegiatan dan Pelaksanaan

Pelaksanaan kegiatan belajar mengajar untuk siklus I dilaksanakan pada tanggal 26 Agustus 2021 di Kelas VI dengan jumlah siswa 21 siswa. Dalam hal ini peneliti bertindak sebagai guru. Adapun proses belajar mengajar mengacu pada rencana pelajaran yang telah dipersiapkan. Pengamatan (observasi) dilaksanakan bersamaan dengan pelaksaaan belajar mengajar. Pada akhir proses belajar mengajar siswa diberi tes formatif I dengan tujuan untuk mengetahui tingkat keberhasilan siswa dalam proses belajar mengajar yang telah dilakukan. Adapun data hasil penelitian pada siklus I adalah sebagai berikut:

Data tes formatif untuk mengetahui peningkatan Hasil Belajar belajar siswa setelah diterapkan belajar dengan metode pembelajaran model kontekstual berbasis masalah adalah sebagai berikut: 
Tabel 1. Distribusi Nilai Tes Pada Siklus I

\begin{tabular}{|c|c|c|c|c|c|c|c|}
\hline \multirow{2}{*}{$\begin{array}{l}\text { No. } \\
\text { Urut }\end{array}$} & \multirow{2}{*}{ Skor } & \multicolumn{2}{|c|}{ Keterangan } & \multirow{2}{*}{$\begin{array}{l}\text { No. } \\
\text { Urut }\end{array}$} & \multirow{2}{*}{ Skor } & \multicolumn{2}{|c|}{ Keterangan } \\
\hline & & $\mathrm{T}$ & TT & & & $\mathrm{T}$ & TT \\
\hline 1 & 80 & $\sqrt{ }$ & & 12 & 30 & & $\sqrt{ }$ \\
\hline 2 & 50 & & $\sqrt{ }$ & 13 & 70 & $\sqrt{ }$ & \\
\hline 3 & 80 & $\sqrt{ }$ & & 14 & 80 & $\sqrt{ }$ & \\
\hline 4 & 60 & & $\sqrt{ }$ & 15 & 70 & $\sqrt{ }$ & \\
\hline 5 & 40 & & $\sqrt{ }$ & 16 & 70 & $\sqrt{ }$ & \\
\hline 6 & 80 & $\sqrt{ }$ & & 17 & 70 & $\sqrt{ }$ & \\
\hline 7 & 70 & $\sqrt{ }$ & & 18 & 80 & $\sqrt{ }$ & \\
\hline 8 & 60 & & $\sqrt{ }$ & 19 & 60 & & $\sqrt{ }$ \\
\hline 9 & 70 & $\sqrt{ }$ & & 20 & 80 & $\sqrt{ }$ & \\
\hline 10 & 80 & $\sqrt{ }$ & & 21 & 100 & $\sqrt{ }$ & \\
\hline 11 & 60 & & $\sqrt{ }$ & Jumlah & 710 & 8 & 2 \\
\hline Jumlah & 730 & 6 & 5 & & & & \\
\hline \multicolumn{8}{|c|}{$\begin{array}{l}\text { Jumlah Skor } 1440 \\
\text { Jumlah Skor Maksimal Ideal } 2100 \\
\text { Rata-Rata Skor Tercapai } 68,57\end{array}$} \\
\hline \multicolumn{2}{|c|}{ Keterangan: } & $\begin{array}{l}\text { nlah } \\
\text { nlah } \\
\text { asika }\end{array}$ & $\begin{array}{l}\text { swa ya } \\
\text { swa ya }\end{array}$ & tuntas & & \multicolumn{2}{|c|}{$\begin{array}{l}\text { : Tuntas } \\
\text { : Tidak Tuntas } \\
: 14 \\
: 7 \\
: \text { Belum tuntas }\end{array}$} \\
\hline
\end{tabular}

Tabel 2. Rekapitulasi Hasil Tes Pada Siklus I

\begin{tabular}{|c|l|c|}
\hline No & \multicolumn{1}{|c|}{ Uraian } & Hasil Siklus I \\
\hline 1 & Nilai rata-rata tes formatif & 68,57 \\
2 & Jumlah siswa yang tuntas belajar & 14 \\
3 & Persentase ketuntasan belajar & 66,67 \\
\hline
\end{tabular}

Dari tabel di atas dapat dijelaskan bahwa dengan menerapkan metode demonstrasi diperoleh nilai rata-rata Hasil Belajar belajar siswa adalah 68,57 dan ketuntasan belajar mencapai 66,67\% atau ada 14 siswa dari 21 siswa sudah tuntas belajar. Hasil tersebut menunjukkan bahwa pada siklus pertama secara klasikal siswa belum tuntas belajar, karena siswa yang memperoleh nilai $\geq 65$ hanya sebesar $66,67 \%$ lebih kecil dari persentase ketuntasan yang dikehendaki yaitu sebesar $85 \%$. Hal ini disebabkan karena siswa masih merasa baru dan belum mengerti apa yang dimaksudkan dan digunakan guru dengan menerapkan metode kontekstual berbasil masalah.. 


\section{Siklus II}

a. Tahap perencanaan

Pada tahap ini peneliti mempersiapkan perangkat pembelajaran yang terdiri dari rencana pelajaran 2, LKS, 2, soal tes formatif II dan alat-alat pengajaran yang mendukung.

b. Tahap kegiatan dan pelaksanaan

Pelaksanaan kegiatan belajar mengajar untuk siklus II dilaksanakan pada tanggal 2 September 2021 di Kelas VI dengan jumlah siswa 21 siswa. Dalam hal ini peneliti bertindak sebagai guru. Adapun proses belajar mengajar mengacu pada rencana pelajaran dengan memperhatikan revisi pada siklus I, sehingga kesalahan atau kekurangan pada siklus I tidak terulang lagi pada siklus II. Pengamatan (observasi) dilaksanakan bersamaan dengan pelaksanaan belajar mengajar.

Pada akhir proses belajar mengajar siswa diberi tes formatif II dengan tujuan untuk mengetahui tingkat keberhasilan siswa dalam proses belajar mengajar yang telah dilakukan. Instrumen yang digunakan adalah tes formatif II. Adapun data hasil penelitian pada siklus II adalah sebagai berikut.

Table 3. Distribusi Nilai Tes Pada Siklus II

\begin{tabular}{|c|c|c|c|c|c|c|c|}
\hline \multirow{2}{*}{$\begin{array}{l}\text { No. } \\
\text { Urut }\end{array}$} & \multirow{2}{*}{ Skor } & \multicolumn{2}{|c|}{ Keterangan } & \multirow{2}{*}{$\begin{array}{l}\text { No. } \\
\text { Urut }\end{array}$} & \multirow{2}{*}{ Skor } & \multicolumn{2}{|c|}{ Keterangan } \\
\hline & & $\mathrm{T}$ & TT & & & $\mathrm{T}$ & TT \\
\hline 1 & 80 & $\sqrt{ }$ & & 12 & 70 & $\sqrt{ }$ & \\
\hline 2 & 70 & $\sqrt{ }$ & & 13 & 60 & & $\sqrt{ }$ \\
\hline 3 & 90 & $\sqrt{ }$ & & 14 & 90 & $\sqrt{ }$ & \\
\hline 4 & 60 & & $\sqrt{ }$ & 15 & 90 & $\sqrt{ }$ & \\
\hline 5 & 50 & . & $\sqrt{ }$ & 16 & 80 & $\sqrt{ }$ & \\
\hline 6 & 60 & & $\sqrt{ }$ & 17 & 80 & $\sqrt{ }$ & \\
\hline 7 & 70 & $\sqrt{ }$ & & 18 & 80 & $\sqrt{ }$ & \\
\hline 8 & 80 & $\sqrt{ }$ & & 19 & 60 & & $\sqrt{ }$ \\
\hline 9 & 80 & $\sqrt{ }$ & & 20 & 80 & $\sqrt{ }$ & \\
\hline 10 & 70 & $\sqrt{ }$ & & 21 & 70 & $\sqrt{ }$ & \\
\hline 11 & 80 & $\sqrt{ }$ & & Jumlah & 760 & 8 & 2 \\
\hline Jumlah & 790 & 8 & 3 & & & & \\
\hline \multicolumn{8}{|c|}{$\begin{array}{l}\text { Jumlah Skor } 1550 \\
\text { Jumlah Skor Maksimal Ideal } 2100 \\
\text { Rata-Rata Skor Tercapai } 73,80\end{array}$} \\
\hline \multicolumn{2}{|c|}{ Keterangan: } & $\begin{array}{l}\text { nlah } \\
\text { nlah } \\
\text { asik }\end{array}$ & $\begin{array}{l}\text { wa ya } \\
\text { wa ya }\end{array}$ & $\begin{array}{l}\text { tuntas } \\
\text { belum }\end{array}$ & & \multicolumn{2}{|c|}{$\begin{array}{l}\text { : Tuntas } \\
: \text { Tidak Tuntas } \\
: 16 \\
: 5 \\
: \text { Belum tuntas }\end{array}$} \\
\hline
\end{tabular}

Tabel 4. Rekapitulasi Hasil Tes Pada Siklus II

\begin{tabular}{|c|l|c|}
\hline No & \multicolumn{1}{|c|}{ Uraian } & Hasil Siklus II \\
\hline 1 & Nilai rata-rata tes formatif & 73,81 \\
2 & Jumlah siswa yang tuntas belajar & 16 \\
3 & Persentase ketuntasan belajar & 76,19 \\
\hline
\end{tabular}

Dari tabel di atas diperoleh nilai rata-rata Hasil Belajar belajar siswa adalah 73,81 dan ketuntasan belajar mencapai $76,19 \%$ atau ada 16 siswa dari 21 siswa sudah tuntas belajar. Hasil ini menunjukkan bahwa pada siklus II ini ketuntasan belajar secara klasikal telah mengalami peningkatan sedikit lebih baik dari siklus I. Adanya peningkatan hasil belajar siswa ini karena setelah guru menginformasikan bahwa setiap akhir pelajaran akan selalu diadakan tes sehingga pada pertemuan berikutnya siswa lebih termotivasi untuk belajar. Selain itu siswa juga sudah 
mulai mengerti apa yang dimaksudkan dan diinginkan guru dengan menerapkan metode model pembelajaran kontekstual berbasis masalah.

\section{Siklus III}

a. Tahap Perencanaan

Pada tahap ini peneliti mempersiapkan perangkat pembelajaran yang terdiri dari rencana pelajaran 3, LKS 3, soal tes formatif 3 dan alat-alat pengajaran yang mendukung.

b. Tahap kegiatan dan pengamatan

Pelaksanaan kegiatan belajar mengajar untuk siklus III dilaksanakan pada tanggal 9 Oktober 2021 di Kelas VI dengan jumlah siswa 21 siswa. Dalam hal ini peneliti bertindak sebagai guru. Adapun proses belajar mengajar mengacu pada rencana pelajaran dengan memperhatikan revisi pada siklus II, sehingga kesalahan atau kekurangan pada siklus II tidak terulang lagi pada siklus III. Pengamatan (observasi) dilaksanakan bersamaan dengan pelaksanaan belajar mengajar.

Pada akhir proses belajar mengajar siswa diberi tes formatif III dengan tujuan untuk mengetahui tingkat keberhasilan siswa dalam proses belajar mengajar yang telah dilakukan. Instrumen yang digunakan adalah tes formatif III. Adapun data hasil penelitian pada siklus III adalah sebagai berikut.

Tabel 5. Rekapitulasi Hasil Tes Pada Siklus III

\begin{tabular}{|c|c|c|c|c|c|c|c|}
\hline \multirow{2}{*}{$\begin{array}{l}\text { No. } \\
\text { Urut }\end{array}$} & \multirow{2}{*}{ Skor } & \multicolumn{2}{|c|}{ Keterangan } & \multirow{2}{*}{$\begin{array}{l}\text { No. } \\
\text { Urut } \\
\end{array}$} & \multirow{2}{*}{ Skor } & \multicolumn{2}{|c|}{ Keterangan } \\
\hline & & $\mathrm{T}$ & TT & & & $\mathrm{T}$ & TT \\
\hline 1 & 80 & $\sqrt{ }$ & & 12 & 70 & $\sqrt{ }$ & \\
\hline 2 & 90 & $\sqrt{ }$ & & 13 & 80 & $\sqrt{ }$ & \\
\hline 3 & 90 & $\sqrt{ }$ & & 14 & 100 & $\sqrt{ }$ & \\
\hline 4 & 60 & & $\sqrt{ }$ & 15 & 90 & $\sqrt{ }$ & \\
\hline 5 & 90 & $\sqrt{ }$ & & 16 & 90 & $\sqrt{ }$ & \\
\hline 6 & 90 & $\sqrt{ }$ & & 17 & 80 & $\sqrt{ }$ & \\
\hline 7 & 90 & $\sqrt{ }$ & & 18 & 90 & $\sqrt{ }$ & \\
\hline 8 & 80 & $\sqrt{ }$ & & 19 & 80 & $\sqrt{ }$ & \\
\hline 9 & 60 & & $\sqrt{ }$ & 20 & 100 & $\sqrt{ }$ & \\
\hline 10 & 80 & $\sqrt{ }$ & & 21 & 80 & $\sqrt{ }$ & \\
\hline 11 & 80 & $\sqrt{ }$ & & Jumlah & 860 & 10 & - \\
\hline Jumlah & 890 & 9 & 2 & & & & \\
\hline \multicolumn{8}{|c|}{$\begin{array}{l}\text { Jumlah Skor } 1750 \\
\text { Jumlah Skor Maksimal Ideal } 2100 \\
\text { Rata-Rata Skor Tercapai 83,33 }\end{array}$} \\
\hline \multicolumn{2}{|c|}{ Keterangan: } & $\begin{array}{l}\text { nlah } \\
\text { nlah } \\
\text { asika }\end{array}$ & $\begin{array}{l}\text { wa ya } \\
\text { wa ya }\end{array}$ & $\begin{array}{l}\text { tuntas } \\
\text { belum } \mathrm{t}\end{array}$ & & \multicolumn{2}{|c|}{$\begin{array}{l}\text { : Tuntas } \\
: \text { Tidak Tuntas } \\
: 19 \\
: 2 \\
: \text { Tuntas }\end{array}$} \\
\hline
\end{tabular}

Tabel 6. Rekapitulasi Hasil Tes Pada Siklus III

\begin{tabular}{|c|l|c|}
\hline No & \multicolumn{1}{|c|}{ Uraian } & Hasil Siklus III \\
\hline 1 & Nilai rata-rata tes formatif & 83,33 \\
2 & Jumlah siswa yang tuntas belajar & 19 \\
3 & Persentase ketuntasan belajar & 90,48 \\
\hline
\end{tabular}

Berdasarkan tabel diatas diperoleh nilai rata-rata tes formatif sebesar 83,33 dan dari 21 siswa yang telah tuntas sebanyak 19 siswa dan 2 siswa belum mencapai ketuntasan belajar. Maka secara klasikal ketuntasan belajar yang telah tercapai sebesar 90,48\% (termasuk kategori 
tuntas). Hasil pada siklus III ini mengalami peningkatan lebih baik dari siklus II. Adanya peningkatan hasil belajar pada siklus III ini dipengaeruhi oleh adanya peningkatan kemampuan guru dalam menerapkan belajar dengan metode model pembelajaran kontekstual berbasis masalah. sehingga siswa menjadi lebih terbiasa dengan pembelajaran seperti ini sehingga siswa lebih mudah dalam memahami materi yang telah diberikan.

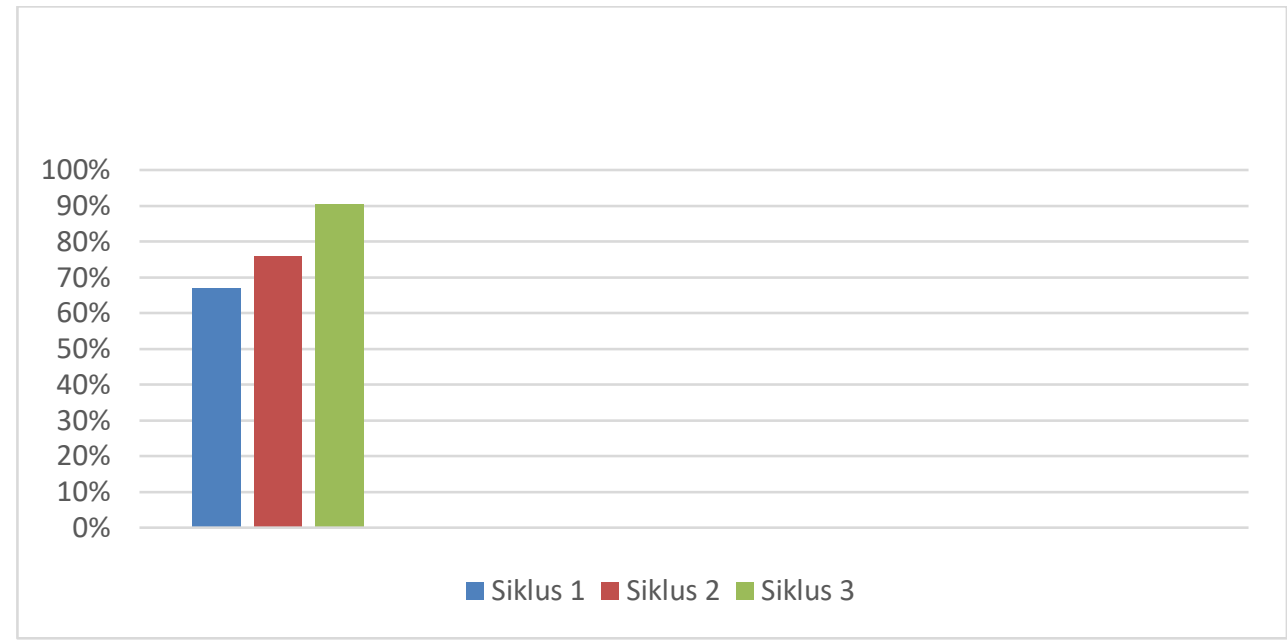

Gambar 1. Grafik Persentase Peningkatan

Dari hasil analis didapatkan bahwa prestasi belajar siswa mengalami peningkatan dari siklus I sampai siklus III yaitu, siklus I (66,67\%), siklus II (76,19\%), siklus III $(90,48 \%)$. Kesimpulan dari penelitian ini adalah metode kontekstual berbasis masalah materi pelajaran dapat berpengaruh positif terhadap motivasi belajar Siswa kelas VI SD Negeri 015 Petala Bumi serta model pembelajaran ini dapat digunakan sebagai salah satu alternatif pembelajaran Matematika.

\section{Pembahasan}

Penelitian ini menggunakan Penelitian Tindakan Kelas (PTK). Menurut Tim Pelatih Proyek PGSM, PTK adalah suatu bentuk kajian yang bersifat reflektif oleh pelaku tindakan yang dilakukan untuk meningkatkan kemantapan rasional dari tindakan mereka dalam melaksanakan tugas, memperdalam pemahaman terhadap tindakan-tindakan yang dilakukan itu, serta memperbaiki kondisi dimana praktek pembelajaran tersebut dilakukan (dalam Mukhlis, 2000: 3).

Sedangkan menurut Mukhlis (2000: 5) PTK adalah suatu bentuk kajian yang bersifat sistematis reflektif oleh pelaku tindakan untuk memperbaiki kondisi pembelajaran yang dilakukan.

Adapun tujuan utama dari PTK adalah untuk memperbaiki/meningkatkan pratek pembelajaran secara berkesinambungan, sedangkan tujuan penyertaannya adalah menumbuhkan budaya meneliti di kalangan guru (Mukhlis, 2000: 5). Sesuai dengan jenis penelitian yang dipilih, yaitu penelitian tindakan, maka penelitian ini menggunakan model penelitian tindakan dari Kemmis dan Taggart (dalam Sugiarti, 1997: 6), yaitu berbentuk spiral dari sklus yang satu ke siklus yang berikutnya. Setiap siklus meliputi planning (rencana), action (tindakan), observation (pengamatan), dan reflection (refleksi).

Metode pengumpulan data dapat dilakukan dengan cara: (1) Observasi (pengamatan langsung) oleh peneliti tentang aktivitas dan sikap siswa pada saat proses pembelajaran. Observasi atau pengamatan adalah usaha sadar untuk mengumpulkan data yang dilakukan secara sistematis dengan prosedur yang standar (Suharsimi Arikunto, 2002:225). 


\section{KESIMPULAN}

Dari hasil kegiatan pembelajaran yang telah dilakukan selama tiga siklus, dan berdasarkan seluruh pembahasan serta analisis yang telah dilakukan dapat disimpulkan sebagai berikut:

1. Pembelajaran dengan metode Kontekstual Berbasis Masalah memiliki dampak positif dalam meningkatkan hasil belajar siswa yang ditandai dengan peningkatan ketuntasan belajar siswa dalam setiap siklus.

2. Penerapan metode Kontekstual Berbasis Masalah mempunyai pengaruh positif, yaitu dapat meningkatkan motivasi belajar siswa yang ditunjukkan dengan rata-rata jawaban siswa hasil wawancara yang menyatakan bahwa siswa tertarik dan berminat dengan metode Kontekstual Berbasis Masalah sehingga mereka menjadi termotivasi untuk belajar

\section{DAFTAR PUSTAKA}

Ali, Muhammad. (1996). Guru Dalam Proses Belajar Mengajar. Bandung: Sinar Baru Algesindon.

Arikunto, Suharsimi. (1998). Prosedur Penelitian Suatu Pendekatan Praktek. Jakarta: Rineksa Cipta

Departemen Pendidikan dan Kebudayaan. (1994). Petunjuk Pelaksanaan Proses Belajar Mengajar. Jakarta. Balai Pustaka.

Dimyati, Mudjiono. (2013). Belajar \& Pembelajaran. Jakarta: Rineka Cipta.

Djamarah, Syaiful Bahri. (2000). Strategi Belajar Mengajar. Jakarta: Rineksa Cipta.

Hamalik, Oemar. (1994). Metode Pendidikan. Bandung: Citra Aditya Bakti.

Hudoyo, H. (1990). Strategi Belajar Mengajar Matematika. Malang: IKIP Malang.

Kemmis, S. dan Mc. Taggart, R. (1988). The Action Research Planner. Victoria Dearcin University Press.

Mukhlis, Abdul. (Ed). (2000). Penelitian Tindakan Kelas. Makalah Panitia Pelatihan Penulisan Karya Ilmiah untuk Guru-guru se-Kabupaten Tuban.

Permendikbud Nomor 62. (2014). Manajemen Ekstrakurikuler dalam Mengembangkan Minat dan Bakat Anak. Jakarta. Balai Pustaka.

Poerwodarminto, Structural Equation Modeling dengan Lisrel 8.8. Graha Ilmu. Yogyakarta.

Suharsimi, Arikunto. (2002). Prosedur Penelitian Suatu Pendekatan praktek. Jakarta: Rineksa Cipta.

Undang-undang RI no. 20 tahun 2003 tentang Sistem Pendidikan Nasional Beserta Penjelasannya, Bandung: Citra Umbara, (2003) 